\title{
ZASILEK DLA BEZROBOTNYCH DETERMINANTĄ PRACY NIEREJESTROWANEJ W ŚWIETLE BADAŃ WŁASNYCH
}

Zasiłek dla bezrobotnych jest świadczeniem mającym z jednej strony zapewnić utrzymanie dotychczasowej stopy życiowej beneficjenta, a z drugiej motywować go do aktywnego poszukiwania nowego zatrudnienia. W literaturze przedmiotu można spotkać się z poglądem, że zbyt niski poziom świadczenia zmusza bezrobotnych do dorabiania w szarej strefie ze względu na niewystarczający poziom środków pieniężnych otrzymywanych w ramach pomocy. Z kolei wskazuje się także, że zbyt wysoki poziom zasiłku lub zbliżony do płacy minimalnej może zachęcać do przepracowywania wymaganego, ustawowego okresu uprawniającego do poboru świadczenia i równoczesnego dorabiania „na czarno”.

W opracowaniu przedstawiono poziom zasiłku dla bezrobotnych oraz zakres pracy nierejestrowanej w Polsce i wybranych krajach w latach 1999-2014. Na podstawie danych statystycznych w oparciu o metodę regresji liniowej zbadano zależność pomiędzy maksymalną wysokością zasiłku przyznawanego bezrobotnym a zakresem pracy nierejestrowanej w Polsce i wybranych krajach. Zaprezentowano także fragmenty własnych badań ankietowych z lat 2007-2015 obejmujących problematykę szarej strefy, w tym nieewidencjonowanej aktywności rynku pracy. W artykule starano się ocenić oddziaływanie wysokości świadczenia dla bezrobotnych na ich skłonność do podejmowania nierejestrowanego zatrudnienia.

W przeprowadzonej analizie statystycznej wykazano, że wysokość świadczenia otrzymywanego przez osoby bezrobotne w Polsce w latach 1999-2014 wpływa na zakres pracy nierejestrowanej obliczanej metodą MIMIC (Multiple Indicators Multiple Causes). Wysokość zasiłku w ponad $80 \%$ determinuje zakres podejmowanej pracy w szarej strefie. Natomiast ze względu na zróżnicowany sposób wyliczania kwoty przysługującego zasiłku nie wykazano zależności statystycznej między wysokością badanego świadczenia a zakresem pracy nierejestrowanej w wybranych krajach europejskich.

Badania ankietowe przeprowadzane na próbie celowej około tysiąca gospodarstw domowych także nie rozstrzygnęły jednoznacznie kwestii wysokości zasiłku motywującego bądź zmuszającego do podejmowania pracy nielegalnej. Sama wysokość świadczenia nie jest jedyną determinantą. nych

Słowa kluczowe: rynek pracy, praca nierejestrowana, bezrobocie, zasiłek dla bezrobot-

\section{WPROWADZENIE}

Praca nierejestrowana definiowana jest jako zjawisko polegające na aktywności na rynku pracy umykające oficjalnym statystykom, od której nie są odprowadzane podatki ani inne obowiązkowe świadczenia na rzecz państwa. Przez pojęcie pracy nierejestrowanej (nielegalnej, nieformalnej) najczęściej rozumie się pracę najemną wykonywaną bez zawarcia formalnej umowy, a także pracę wykonywaną w podstawowym miejscu pracy,

\footnotetext{
${ }^{1}$ Monika Pasternak-Malicka, dr, Politechnika Rzeszowska, Wydział Zarządzania, Zakład Finansów i Bankowości, Al. Powstańców Warszawy 10,35-959 Rzeszów, tel.: 1786519 12, e-mail: malicka@prz.edu.pl
} 
ale w ramach której wynagrodzenie jest częściowo wypłacane poza ewidencją oraz nieewidencjonowaną pracę na własny rachunek.

Najczęstszą przyczyną wskazywaną w literaturze przedmiotu, a także sugerowaną przez badania empiryczne rynku pracy są wysokie podatki i składki na ubezpieczenia społeczne ${ }^{2}$. Innym ważnym czynnikiem przyczyniającym się do wzmożonej aktywności w szarej strefie rynku pracy jest intensywność uregulowań prawnych, które ograniczają swobodę wyboru pracodawcy lub pracownika, a także przyczyniają się do wzrostu kosztów funkcjonowania w oficjalnej gospodarce ${ }^{3}$. Rozrost pracy nierejestrowanej może prowadzić do zmniejszenia dochodów budżetowych, co z kolei powoduje zmniejszenie ilości i pogorszenie jakości dóbr i usług oferowanych przez sektor publiczny. Skutkiem może być sytuacja, w której pomoc socjalna trafia do osób mniej lub wcale jej nie potrzebujących. Uregulowania prawne obejmują również określanie wysokości, warunków przyznawania i okresu wypłacania świadczeń socjalnych, w tym zasiłków dla bezrobotnych.

Zasiłki dla bezrobotnych, określane także jako ubezpieczenie na wypadek utraty pracy lub odszkodowanie na wypadek bezrobocia, są świadczeniem mającym zapewnić standard życia na dotychczasowym lub minimalnym poziomie - w zależności od prowadzonej w danym państwie polityki społecznej. W ramach opieki socjalnej oferowanej przez kraje Europy Zachodniej zasiłek ma stanowić pewnego rodzaju rekompensatę za utracone dochody. W Polsce funkcją tego świadczenia jest zapewnienie minimalnych środków do przeżycia. Drugą funkcją zasiłków dla bezrobotnych jest zwiększenie motywacji do podjęcia pracy zgodnej z kwalifikacjami beneficjenta.

Można się spotkać z opinią, że wysokość świadczenia w Polsce jest tak niska, że degraduje tracącego pracę i nie pozwala na funkcjonowanie na dotychczasowym poziomie. Mimo to nie spełnia funkcji motywującej do poszukiwania legalnej pracy, a raczej zachęca do podejmowania pracy w szarej strefie $\mathrm{z}$ jednoczesnym pobieraniem zasiłku. Celem publikacji jest próba rozważenia tego problemu i odpowiedź na pytanie, czy zasiłek dla bezrobotnych o relatywnie niskim poziomie motywuje, zniechęca, czy jest obojętny dla aktywności w szarej strefie rynku pracy.

\section{POZIOM PRACY NIEREJESTROWANEJ}

Praca nierejestrowana w Polsce jest wciąż powszechnym zjawiskiem, choć najwyższy jej poziom przypadał na pierwszą połowę lat dziewięćdziesiątych. W tabeli 1 przedstawiono udział szarej gospodarki, w tym pracy nierejestrowanej, w tworzeniu produktu krajowego brutto (PKB) w latach 1999-2012 według szacunków Głównego Urzędu Staty-

\footnotetext{
2 P.M. Gutmann, The Subterranean Economy, „Financial Analysts Journal” 1977/33; J.J. Thomas, Informal Economic Activity, LSE, Handbooks in Economics, Harvester Wheatsheaf, London 1992; V. Tanzi, Uses and abuses of estimates of the underground economy, „The Economic Journal” 109/456 (1999); F. Schneider, The shadow economies of Western Europe, ,Journal of the Institute of Economic Affairs”, $17 / 3$ (1997); M. Bednarski, R. Kokoszczyński, Nieoficjalna gospodarka i jej społeczne nastepstwa, „Ekonomista” 1988/3-4, s. 702-703; P. Gaudemet, Finanse publiczne, Polskie Wydawnictwo Ekonomiczne, Warszawa 2000, s. 575 i n.; H. Zarychta, Szara strefa rynku pracy w Polsce, cz. I, „Praca i Zabezpieczenia Społeczne” 1993/12, s. 11; B Mróz, Gospodarka nieoficjalna w systemie ekonomicznym, Szkoła Główna Handlowa, Warszawa 2002, s. 42.

${ }^{3}$ E. Fridman, S. Johnson, D. Kaufmann, P. Zoido-Labton, Dodging the grabbing hand: The determinants of unofficial activity in 69 countries, ,Journal of Public Economics” 76/4 (2000); S. Johnson, D. Kaufmann, P. Zoido-Labton, Corruption, public finances and the unofficial economy, The World Bank, Washington 1998; S. Mateman, P.H. Renooy, Undeclared Labour in Europe: Towards an Integrated Approach of Combating Undeclared Labour, Regoiplan, Amsterdam 2001.
} 
stycznego (GUS) oraz Friedricha Schneidera w latach 1999-2014. Według GUS udział ten kształtował się w badanym okresie na poziomie od 3,2\% do 5,3\% PKB i wykazywał tendencję malejącą. $\mathrm{W}$ analizowanych latach większy wpływ na rozmiary aktywności w strefie nieformalnej miała działalność gospodarcza prowadzona w zarejestrowanych podmiotach gospodarczych. Największy udział w szarej strefie miały podmioty prowadzące działalność handlową, budowlaną oraz obsługi rynku nieruchomości.

Tabela 1. Szara strefa gospodarki oraz praca nielegalna według Głównego Urzędu Statystycznego (GUS) i Friedricha Schneidera w Polsce w latach 1999-2014 (\%)

\begin{tabular}{|l|r|r|r|r|r|r|r|r|}
\hline Lata & 1999 & 2000 & 2001 & 2002 & 2003 & 2004 & 2005 & 2006 \\
\hline $\begin{array}{l}\text { Szara gospodarka według } \\
\text { GUS }\end{array}$ & 14,5 & 17,0 & 16,3 & 15,3 & 15,4 & 14,4 & 13,7 & 13,7 \\
\hline $\begin{array}{l}\bullet \\
\text { na praca }\end{array}$ & 5,3 & 5,3 & 5,2 & 5,2 & 5,1 & 4,9 & 4,2 & 4,0 \\
\hline $\begin{array}{l}\text { Szara gospodarka według } \\
\text { Schneidera }\end{array}$ & 27,7 & 27,6 & 28,2 & 28,9 & 27,7 & 27,4 & 27,1 & 26,8 \\
\hline $\begin{array}{l}\bullet \quad \text { w tym nielegal- } \\
\text { na praca* }\end{array}$ & 9,2 & 9,2 & 9,4 & 9,6 & 9,2 & 9,1 & 9,0 & 8,9 \\
\hline Lata w tym niele- & 2007 & 2008 & 2009 & 2010 & 2011 & 2012 & 2013 & 2014 \\
\hline $\begin{array}{l}\text { Szara gospodarka według } \\
\text { GUS }\end{array}$ & 12,8 & 11,8 & 13,1 & 12,8 & 12,6 & 14,5 & - & - \\
\hline $\begin{array}{l}\bullet \\
\text { galna praca }\end{array}$ & 3,5 & 3,5 & 3,3 & 3,2 & 3,3 & - & - \\
\hline $\begin{array}{l}\text { Szara gospodarka według } \\
\text { Schneidera }\end{array}$ & 26,0 & 25,3 & 25,9 & 25,4 & 25,0 & 24,4 & 23,8 & 23,5 \\
\hline $\begin{array}{l}\bullet \quad w \\
\text { na praca* tym nielegal- }\end{array}$ & 8,7 & 8,4 & 8,6 & 8,5 & 8,3 & 8,1 & 7,9 & 7,8 \\
\hline
\end{tabular}

* Przyjęto wskaźniki procentowe na poziomie 1/3 udziału szarej strefy w PKB.

Źródło: opracowanie własne na podstawie: Rachunki narodowe wg sektorów i podsektorów instytucjonalnych $w$ latach 2007-2011, Studia i analizy statystyczne, GUS, Warszawa 2013, s. 373-374; Rachunki narodowe wg sektorów i podsektorów instytucjonalnych $w$ latach 2009-2012, Studia i analizy statystyczne, GUS, Warszawa 2014, s. 365-372; F. Schneider, The Size of the Shadow Economies of 145 Countries all over the World, First Results over the Period 1999 to 2003, IZA, Discussion Paper, 2004/1431; F. Schneider, Size and Development of the Shadow Economy of 31 European and 5 other OECD Countries from 2003 to 2013, www.uni-linz.ac.at, 2013; F. Schneider, K. Raczkowski, B. Mróz, Shadow economy and tax evasion in the EU, ,Journal of Money Laundering Control" 18/1(2015), s. 12.

Natomiast szacunki Friedricha Schneidera ${ }^{4}$ wskazują na szerszy zakres pracy nieformalnej w Polsce, który utrzymywał się na poziomie wyższym średnio o 4-5 punktów procentowych. Ponadto wskaźnik ten charakteryzował się już bardziej zmienną dynamiką - do 2002 r. odnotowano wzrost, w kolejnych latach, wraz z poprawą koniunktury, zakres pracy nierejestrowanej w 2008 r. zmalał do 8,4\% PKB, po czym wraz ze spowolnieniem

\footnotetext{
${ }^{4} \mathrm{~W}$ badaniach nad szarą strefą gospodarki specjalizuje się Friedrich Schneider, który na podstawie metody MIMIC (Multiple Indicators Multiple Causes) oblicza udział gospodarki nieformalnej w PKB.
} 
gospodarczym, będącym skutkiem kryzysu subprime, wskaźnik wzrósł nieznacznie w kolejnym roku, aby ponownie obniżyć się do poziomu 7,8\% PKB w 2014 r.

Tabela 2. Szara strefa rynku pracy według Friedricha Schneidera w wybranych krajach w latach 2000-2014 (\%)

\begin{tabular}{|l|c|c|c|c|c|c|c|c|c|c|c|c|c|c|c|}
\hline Kraj & 2000 & 2001 & 2002 & 2003 & 2004 & 2005 & 2006 & 2007 & 2008 & 2009 & 2010 & 2011 & 2012 & 2013 & 2014 \\
\hline Austria & 3,3 & 3,5 & 3,6 & 3,6 & 3,7 & 3,4 & 3,2 & 3,1 & 2,7 & 2,8 & 2,7 & 2,6 & 2,5 & 2,5 & 2,6 \\
\hline Butgania & 12,3 & 12,4 & 12,8 & 120 & 11,8 & 11,5 & 11,3 & 10,9 & 10,7 & 10,8 & 10,9 & 10,8 & 10,6 & 10,4 & 10,3 \\
\hline Francja & 5,1 & 5,0 & 4,8 & 4,9 & 4,8 & 4,6 & 4,1 & 3,9 & 3,7 & 3,9 & 3,8 & 3,7 & 3,6 & 3,3 & 3,6 \\
\hline Niemcy & 6,0 & 6,0 & 5,8 & 5,7 & 5,4 & 5,1 & 5,0 & 4,9 & 4,7 & 4,9 & 4,6 & 4,6 & 4,4 & 4,3 & 4,4 \\
\hline Grecja & 9,6 & 9,5 & 9,4 & 9,4 & 9,4 & 9,2 & 8,7 & 8,4 & 8,1 & 8,3 & 8,5 & 8,1 & 8,0 & 7,9 & 7,8 \\
\hline Hispania & 7,6 & 7,5 & 7,3 & 7,4 & 7,3 & 7,1 & 6,7 & 6,4 & 6,1 & 6,5 & 6,5 & 6,4 & 6,4 & 6,2 & 6,2 \\
\hline $\begin{array}{l}\text { Wielka } \\
\text { Brytania }\end{array}$ & 4,2 & 4,2 & 4,1 & 4,1 & 4,1 & 4,0 & 3,7 & 3,5 & 3,4 & 3,6 & 3,6 & 3,5 & 3,4 & 3,2 & 3,2 \\
\hline Holandia & 4,4 & 4,4 & 4,4 & 4,4 & 4,4 & 4,4 & 4,4 & 4,2 & 3,2 & 3,4 & 3,3 & 3,3 & 3,2 & 3,0 & 3,0 \\
\hline Norwegia & 6,4 & 6,3 & 6,3 & 6,3 & 6,2 & 6,2 & 6,1 & 6,0 & 4,9 & 5,1 & 5,0 & 4,9 & 4,7 & 4,5 & 4,4 \\
\hline Szwecja & 6,4 & 6,4 & 6,3 & 6,3 & 6,2 & 6,2 & 6,1 & 6,0 & 5,0 & 5,1 & 5,0 & 4,9 & 4,8 & 4,6 & 4,5 \\
\hline Włochy & 9,0 & 8,9 & 8,9 & 9,0 & 9,0 & 9,0 & 9,0 & 9,0 & 7,1 & 7,3 & 7,3 & 7,0 & 7,2 & 7,0 & 6,9 \\
\hline
\end{tabular}

Źródło: opracowanie własne na podstawie: F. Shneider, The Size of the Shadow Economies of 145 Countries all over the World, First Results over the Period 1999 to 2003, „IZA, Discussion Paper” 2004/1431; F. Schneider, Size and Development of the Shadow Economy of 31 European and 5 other OECD Countries from 2003 to 2013, www.uni-linz.ac.at, 2013; F. Schneider, K. Raczkowski, B. Mróz, Shadow economy and tax evasion in the EU, ,Journal of Money Laundering Control” 18/1 (2015), s. 12.

Z raportu przygotowanego przez Komisję Europejską wynika, że szara strefa rynku pracy wciąż się rozwija ${ }^{5}$. Autorzy raportu wskazują na wieloaspektowość zjawiska - począwszy od opieki nad dziećmi, aż po coraz powszechniejszą pracę na pełen etap w firmach. W tabeli 2 zaprezentowano zakres szarej strefy rynku pracy w wybranych krajach wchodzących w skład Unii Europejskiej w latach 2000-2014 według szacunków Schneidera. Tradycyjnie kraje o północnej mentalności podatkowej charakteryzuje niższy zakres pracy nierejestrowanej (najmniejszy poziom odnotowano w Austrii - 2,6\% PKB w 2014 r.), natomiast $\mathrm{w}$ krajach południowych i dawnego bloku wschodniego udział tego zjawiska w PKB jest zdecydowanie wyższy (Bułgaria - 10,3\% PKB w 2014 r.).

\section{WYSOKOŚĆ ZASILKU W POLSCE I WYBRANYCH KRAJACH}

Zasiłek dla osób pozostających bez pracy w Polsce jest świadczeniem socjalnym, które uregulowane jest mocą „Ustawy z 20 kwietnia 2004 r. o promocji zatrudnienia i instytucjach rynku pracy" (DzU 2013 poz. 674, ze zm.). Warunkiem otrzymania świadczenia jest posiadanie urzędowego statusu bezrobotnego, odprowadzanie pełnych składek na Fundusz Pracy w Polsce lub innych krajach Unii Europejskiej przez 365 dni w ciągu ostatnich 18 miesięcy $^{6}$.

\footnotetext{
${ }^{5}$ Komisja Europejska, Komunikat Prasowy, Bruksela, 9 kwietnia 2014 r., w sprawie skuteczniejszego zapobiegania pracy nierejestrowanej i zniechęcania do niej, http:// Europa.eu/rapie/Press-release_IP-14-387.

${ }^{6}$ DzU 2013 poz. 674, ze zm.
} 
Tabela 3. Wysokość zasiłku dla bezrobotnych w Polsce w latach 1998-2016 (zł)

\begin{tabular}{|c|c|c|c|c|}
\hline Lata & $\begin{array}{c}\text { Kwota } \\
\text { bazowa }\end{array}$ & $\begin{array}{c}\text { Kwota bazowa } \\
\text { w kolejnych } \\
\text { miesiącach }\end{array}$ & $\begin{array}{c}\text { Kwota maks. } \\
\text { (120\% kwoty } \\
\text { bazowej) }\end{array}$ & $\begin{array}{c}\text { Wysokość min. } \\
\text { (80\% kwoty } \\
\text { bazowej) }\end{array}$ \\
\hline 1.III.1998-31.V.1998 & 350,70 & - & - & - \\
\hline 1.VI.1998-31.VIII.1998 & 370,40 & - & - & - \\
\hline 1.IX.1998-30.XI.1998 & 378,20 & - & - & - \\
\hline 1.XII.1998-28.II.1999 & 378,20 & - & - & - \\
\hline 1.III.1999-31.V.1999 & 383,90 & - & - & - \\
\hline 1.VI.1999-31.VIII.1999 & 393,90 & - & - & - \\
\hline 1.IX.1999-30.XI.1999 & 402,60 & - & - & - \\
\hline 1.XII.1999-29.II.2000 & 406,30 & - & & - \\
\hline 1.III.2000-31.V.2000 & 419,30 & - & - & - \\
\hline 1.VI.2000-31.VIII.2000 & 434,90 & - & - & - \\
\hline 1.IX.2000-28.II.2001 & 446,70 & - & - & - \\
\hline 1.III. 2001-31.VIII.2001 & 461,90 & - & - & - \\
\hline 1.IX.2001-31.VIII.2002 & 476,70 & - & - & - \\
\hline 1.IX.2002-31.VIII.2003 & 498,20 & - & 597,90 & 398,60 \\
\hline 1.IX.2003-29.II.2004 & 503,20 & - & 603,90 & 402,60 \\
\hline 1.III. 2004-31.V.2004 & 504,20 & - & 605,10 & 403,40 \\
\hline 1.VI.2004-31.V.2005 & 504,20 & - & 605,10 & 403,40 \\
\hline 1.VI.2005-31.V.2006 & 521,90 & - & 626,30 & 417,60 \\
\hline 1.VI.2006-31.V.2007 & 532,90 & - & 639,50 & 426,40 \\
\hline 1.VI. 2007-31.V.2008 & 538,30 & - & 646,00 & 430,70 \\
\hline 1.VI.2008-31.V.2009 & 551,80 & - & 662,20 & 441,50 \\
\hline 1.VI.2009-31.XII.2009 & 575,00 & - & 690,00 & 460,00 \\
\hline 1. I. $2010-31 . V .2010$ & 717,00 & 563,00 & 860,40 & 573,60 \\
\hline 1.VI. 2010-31.V.2011 & 742,10 & 582,70 & 890,60 & 593,70 \\
\hline 1.VI. 2011-31.V.2012 & 761,4 & 597,90 & 913,70 & 609,20 \\
\hline 1.VI. 2012-31.V.2013 & 794,20 & 623,60 & 953,0 & 635,4 \\
\hline 1. VI. 2013-31.V.2014 & 823,60 & 568,50 & 988,40 & 658,90 \\
\hline 1. VI. 2014-31 V.2015 & 831,10 & 652,60 & 997,40 & 664,90 \\
\hline 1 VI. 2015-31 V.2016 & 831,10 & 652,60 & 997,40 & 664,90 \\
\hline
\end{tabular}

Źródło: Obwieszczenie ministra pracy i Polityki Społecznej z lat 2002-2015, sap.sejm.gov.pl; podstawa prawna: DzU $1998 \mathrm{nr}$ 5, poz. 89; Dz. $1999 \mathrm{nr}$ 6, poz. 71; DzU $2001 \mathrm{nr} 6$, poz. 56; M.P. 2002 nr 40 po. 588; DzU 2004 nr 99, poz. 1001; DzU 2008 nr 69, poz. 415; DzU 2015 nr 19, poz. 149. 
Wysokość świadczenia zależy od stażu pracy. Kwota bazowa wynosi obecnie 831,10 $\mathrm{zł}^{7}$ brutto i dotyczy osób ze stażem pracy 5-20 lat. Taka kwota zasiłku wypłacana jest przez trzy miesiące, następnie zmniejsza się ją do wysokości 652,60 zł brutto. Osobom pracującym krócej niż 5 lat należy się $80 \%$ podstawowej kwoty świadczenia, natomiast bezrobotni o stażu dłuższym niż 20 lat mają prawo do wypłaty $120 \%$ kwoty bazowej. Okres pobierania zasiłku wynosi 6 miesięcy $^{8}$. Wyjątek stanowią osoby powyżej 50. roku życia, które mają przepracowane co najmniej 20 lat. W tym wypadku czas wypłaty zasiłku przedłużony jest do roku. W tabeli 3 zaprezentowano wysokość zasiłku w Polsce w latach 1998-2015. Kwota zasiłku do 2010 r. była taka sama przez cały okres poboru świadczenia, a do września 2002 r. nie różnicowano także wysokości zasiłku ze względu na staż pracy.

Zasiłek wypłacany w Polsce jest często wielokrotnie niższy od świadczenia, jakie otrzymują osoby tracące pracę w krajach Unii Europejskiej. W większości państw kwota pomocy zależy od wysokości utraconych zarobków. W Danii przez pierwsze 12 miesięcy bezrobotny może dostawać zasiłek równy nawet $90 \%$ swojego wynagrodzenia otrzymywanego od pracodawcy w ostatnim miejscu pracy ${ }^{9}$. W tabeli 4 przedstawiono maksymalne stawki w Polsce i wybranych krajach, jakie osoba tracąca pracę mogła uzyskać w 2014 r.

Poszczególne kraje Unii Europejskiej w bardzo zróżnicowany sposób przyznają wysokość i okres poboru świadczenia dla osób bezrobotnych. W Rumunii zasiłek przysługuje osobom, które przepracowały przynajmniej 6 miesięcy w ciągu ostatniego półtora roku. Jego wysokość jest indywidualna i zależy od wysokości dochodów i okresów składkowych, przy czym minimalne wynagrodzenie wynosi około $600 \mathrm{zf}^{10}$. Natomiast w Bułgarii zasiłek wynosi $60 \%$ średniego miesięcznego wynagrodzenia i przysługuje osobom, które płaciły pełne składki na ubezpieczenie społeczne przez nie mniej niż 9 z 15 miesięcy przed rozwiązaniem umowy o pracę. W Bułgarii ustalana jest stawka dzienna, którą następnie mnożony się przez liczbę dni. W 2015 r. minimalna kwota wynosiła 7,20 BGN ${ }^{11}$.

W Holandii wysokość zasiłku nie jest wygórowana - Werkloosheidswet (WW) przysługuje osobom, które przepracowały w tym kraju co najmniej 26 tygodni w ciągu ostatnich dziewięciu miesięcy. Natomiast maksymalny okres wypłaty świadczenia jest długi i wynosi 38 miesięcy. Przez pierwsze dwa miesiące bezrobotny otrzymuje $75 \%$ ostatniego wynagrodzenia, a w następnych $-70 \%$. Ustalony jest limit maksymalny wynoszący 177,03 euro na tydzień. Od 2015 r. maksymalne wypłaty WW ograniczono do stawki dziennej nieprzekraczającej 197 euro, co stanowi około 35000 euro rocznie ${ }^{12}$.

\footnotetext{
${ }^{7}$ Kwota bazowa zasiłku podlega corocznej waloryzacji z dniem 1 czerwca danego roku i obowiązuje od 1 czerwca do 31 maja. Zgodnie z obwieszczeniem Ministra Pracy i Polityki Społecznej z 16 maja 2014 r kwota ta od 1 czerwca 2015 r. do 31 maja 2016 r. wynosi 831,10 zł w pierwszych trzech miesiącach prawa do zasiłku.

${ }^{8}$ Art. 72 ust. 6 z 20 kwietnia 2004 r. o promocji zatrudnienia i instytucjach rynku pracy (DzU 2015 poz.149; Obwieszczenie MIPS z 16 maja 2014 r. w sprawie wysokości zasiłku dla bezrobotnych.

${ }^{9}$ www. expatindenmark.com; www.a-kasser.dk/benefits.

${ }^{10}$ Your social security rights in Romania, Employment, Social and Inclusion, European Commission, 2013, http://ec.europa.eu; U.S. Social Security Administration, www.ssa.gov.

${ }^{11}$ Unemployment benefits 2015, National Social Security Institute, www.nssi.bg.

${ }^{12}$ The Unemployment Benefits Act (WW), www. Iamexpat.nl.
} 
Tabela 4. Maksymalna wysokość zasiłku dla bezrobotnych brutto w wybranych krajach w 2014 r. (w skali miesiąca)

\begin{tabular}{|c|c|c|}
\hline Kraj & Euro & $\mathrm{ZY} *$ \\
\hline Polska & 237 & 988,4 \\
\hline Niemcy ${ }^{(1)}$ & 1530 & 6380,1 \\
\hline Wielka Brytania ${ }^{(2)}$ & 1401,8 & 5845,5 \\
\hline Holandia $^{(3)}$ & 761,2 & 3174,3 \\
\hline Norwegia $^{(4)}$ & 1304 & 8765,12 \\
\hline Szwecja ${ }^{(5)}$ & 2244,6 & 9360 \\
\hline Francja $^{(6)}$ & 799,8 & 3335,2 \\
\hline Hiszpania & 1400 & 5838 \\
\hline Włochy & 1180 & 4920,6 \\
\hline Austria & 2719 & 11338,2 \\
\hline Bułgaria ${ }^{(7)}$ & 104,4 & 435,3 \\
\hline Grecja & 360 & 1501,2 \\
\hline
\end{tabular}

*Kurs euro przyjęto na poziomie 1 EUR = 4,17 PLN.

(1) Arbeitslosengeld I liczony w wysokości $67 \%$ od kwoty 1700 euro miesięcznie (wynagrodzenie początkowe specjalisty od gastronomii) - otrzymane 1139 euro powiększono o Harz IV w wysokości 391 euro.

(2) Kwota 72,4 funta Cintribution-based JSA/tydzień + 326 funtów Income-based JSA/ tydzień $\times$ 4,3 tygodnia.

(3) Kwotę 177,03 euro pomnożono $\times$ 4,3 tygodnia.

(4) Wysokość zasiłku maksymalnego w Norwegii obliczono jako 62,4\% płacy minimalnej obowiązującej w 2014 r. (stawka godzinowa minimalna - 104 korony, kurs 1 NOK = 0,49 PLN).

(5) Zasiłek dzienny w wysokości 680 koron szwedzkich, kurs korony szwedzkiej przyjęto na poziomie 1 korona szwedzka $=0,44 \mathrm{zł}$

(6) Przyjęto minimalną stawkę dzienną w wysokości 26,66 euro i pomnożono przez 30 dni.

(7) Obliczono jako $60 \%$ minimalnego miesięcznego dochodu. Minimalne wynagrodzenie w Bułgarii wynosiło 174 euro w $2014 \mathrm{r}$

Źródło: opracowanie własne.

W Norwegii Dagpenger ma zastąpić utracony zarobek i stymulować do poszukiwania nowej pracy. Aby uzyskać prawo do poboru tego świadczenia, bezrobotny musi udokumentować, że utrata pracy nie nastąpiła z winy pracownika i jest on osobą aktywnie poszukującą zatrudnienia. Zasiłek można pobierać maksymalnie przez 104 tygodnie, a jego przeciętna wysokość to $62,4 \%$ poprzedniego wynagrodzenia brutto ${ }^{13}$. Od poziomu utraconych zarobków zależy także wysokość świadczenia przyznawanego w Austrii - około $55 \%$ stawki dziennej dotychczasowego wynagrodzenia netto danej osoby. Ustawa o ubezpieczeniu społecznym ustala minimalną wysokość zasiłku - od 1 stycznia 2015 r. jest to 872,31 euro. Określona jest jednak maksymalna wysokość tego świadczenia i wynosi ona 2719 euro $^{14}$.

W Grecji wszyscy pracownicy należący do systemu ubezpieczeń społecznych (do systemu ubezpieczenia chorobowego) są automatycznie objęci ubezpieczeniem od utraty pracy. Wysokość zasiłku bazowego w 2014 r. wynosiła 360 euro $^{15}$. Kwota ta zwiększa się

\footnotetext{
${ }^{13}$ Unemployment Benefits, www.nav.no.

${ }^{14}$ Unemployment benefits, Public Employment Service Austria (AMS), www.ams.at.

15 Your social security rights in Grece, Employment, Social and Inclusion, European Commission, 2013, http://ec.europa.eu; OAED Unemployment Benefits in Greek, www.oaed.gr, 2015.
} 
o $10 \%$ na każdego członka rodziny pozostającego na utrzymaniu osoby uprawnionej do otrzymywania świadczenia.

W Niemczech występują dwie formy pomocy dla osób bezrobotnych. Podstawową jest Arbeitslosengeld I, który otrzymują osoby odprowadzające składki na ubezpieczenie społeczne przez co najmniej $360 \mathrm{dni}^{16}$. Wysokość tego świadczenia zależy od otrzymywanego wynagrodzenia, wieku bezrobotnego oraz liczby dzieci znajdujących się na utrzymaniu świadczeniobiorcy. Występują dwie stawki: 60\% ostatniego dochodu netto otrzymują osoby bezdzietne i samotne oraz $67 \%$ ostatniego wynagrodzenia należy się bezrobotnym posiadającym dzieci poniżej 18. roku życia ${ }^{17}$.

Ponadto od 1 stycznia 2005 r. wprowadzono w Niemczech dodatkowy rodzaj świadczenia Arbeitslosengeld II, zwany potocznie Harz IV. Jego stawki także zależą od statusu społecznego osoby uprawnionej do poboru zasiłku ${ }^{18}$. W 2015 r. wysokość stawki wynosiła: dla osoby samotnej 399 euro (w 2014 r. - 391 euro), dla mieszkającej z partnerem 360 euro (w 2014 r. - 353 euro), dla młodych osób pomiędzy 14. a 18. rokiem życia 302 euro (2014 r. - 296 euro), dla dzieci w wieku 6-14 lat kwota pomocy wynosiła w 2015 r. 267 euro (2014 r. - 261 euro) oraz dzieci poniżej 6. roku życia - 234 euro (w 2014 r. -229 euro) ${ }^{19}$.

W Wielkiej Brytanii zasiłek przysługuje nie tylko osobom bezrobotnym, ale także tym, które pracują w niepełnym wymiarze godzin (poniżej 16 godzin tygodniowo) oraz opiekującym się osobami niepełnosprawnymi, starszymi lub małymi dziećmi (do 15. tygodnia). Podstawowym świadczeniem jest Jobseeker's Allowance (JSA), wyróżnia się dwie formy tego świadczenia. Pierwsza to Contribution-based JSA przypominająca zasiłek występujący w Polsce. Zasiłek ten wypłacany był tygodniowo w kwocie 57,90 funtów w 2015 r. (w 2014 r. - 57,35 funtów) osobom nieprzekraczającym 25. rok życia lub w wysokości 73,10 funtów w 2015 r. (w 2014 r. - 72,40 funtów) bezrobotnym w wieku 25 lat $\mathrm{i}$ więcej ${ }^{20}$.

Osoby, które nie odprowadzały w wystarczającej wysokości składek na ubezpieczenie społeczne i jednocześnie otrzymują niskie dochody, mogą się ubiegać o Income-based $J S A$. Świadczenie to nie dotyczy osób mających zgromadzone oszczędności w kwocie powyżej 16 tysięcy funtów lub jeśli ich partner pracuje powyżej 24 godzin tygodniowo. Stawki zależą od sytuacji rodzinnej.

\section{METODYKA BADAWCZA ZASTOSOWANA W PUBLIKACJI}

W celu określenia zależności statystycznej między poziomem pracy nierejestrowanej a wysokością zasiłku pobieranego przez osoby bezrobotne posłużono się metodą regresji liniowej. Jest to metoda estymowania wartości oczekiwanej zmiennej y przy określonych, znanych wartościach innej zmiennej $x$ (lub kilku zmiennych). Przyjmuje się, że szukana zmienna $y$ jest określana jako zmienna objaśniania lub zależna. Natomiast zmienne $x$ nazywa się zmiennymi objaśniającymi lub niezależnymi.

\footnotetext{
${ }^{16}$ Arbeitslosengeld 1 Rechner, www.brutto-netto-rechner.info.

${ }^{17} \mathrm{http}: / /$ ec.europa.eu.

${ }^{18}$ Wie hoch ist der Hartz IV - Regelsatz ab dem 01.01.2015?, Sozialrecht, 2014, www.refrago.de.

${ }^{19} \mathrm{http}: / /$ ec.europa.eu.

${ }^{20}$ Jobseeker's Allowance (JSA), 2015, www.gov.uk.
} 
Metoda ta umożliwia ilościową ocenę występującego związku pomiędzy dwoma badanymi aspektami zjawisk. Określana jest regresją liniową, gdyż zakładanym modelem zależności między zmiennymi zależnymi a niezależnymi jest funkcja liniowa. Tak jak w analizie korelacji, jeżeli jedna wartość wzrasta, to druga wzrasta (dodatnia korelacja) lub spada (ujemna korelacja). W przytoczonej regresji zakłada się, że wzrostowi jednej zmiennej (predyktor) towarzyszy wzrost lub spadek drugiej zmiennej.

Analiza modelu regresji dostarcza informacji, czy poszczególne predyktory (zmienne wprowadzone do modelu liniowego) są istotne statystycznie - czy któryś z nich jest zbędny bądź przydatny do oszacowania zmiennej zależnej. Na podstawie opisanej metody dokonano próby oceny zależności pomiędzy zakresem nieformalnego zatrudnienia a poziomem zasiłku dla bezrobotnych w Polsce i wybranych krajach.

Aby poszerzyć analizę statystyczną, posłużono się także metodą bezpośrednią - ankietową. Jest to metoda badań naukowych polegająca na stawianiu pytań, a następnie opracowywaniu odpowiedzi. Odgrywa ona podstawową rolę w naukach społecznych, a także wszędzie tam, gdzie badaczowi zależy na poznaniu opinii respondentów w oparciu na udzielonych przez nich wypowiedzi. Jest to szczególnie przydatna metoda w analizowaniu i interpretacji zjawisk trudnych do ewidencjonowania, jak na przykład gospodarki nieformalnej bądź jednej jej formy, czyli pracy nierejestrowanej. Uzyskane odpowiedzi mogą pozwolić na szersze spojrzenie na daną problematykę i pogłębienie danych uzyskanych z szacunków statystycznych na temat zjawisk, które często umykają oficjalnym statystykom.

\section{ZALEŻNOŚĆ STATYSTYCZNA POMIĘDZY ŚWIADCZENIEM DLA BEZ- ROBOTNYCH A ZAKRESEM PRACY NIEREJESTROWANEJ}

W tej części publikacji określono zależność statystyczną między poziomem pracy nierejestrowanej a wysokością zasiłku pobieranego przez osoby bezrobotne. Na rysunkach 1-3 zaprezentowano wykres rozrzutu, będący graficzną interpelacją korelacji pomiędzy wysokością zasiłku a zakresem pracy nierejestrowanej. Wszystkie trzy zależności pokazują zależność ujemną, co może oznaczać, że wzrostowi kwoty zasiłku dla bezrobotnych będzie towarzyszył spadek zatrudnienia w szarej strefie rynku pracy.

Na rysunku 1 przedstawiono wspomnianą zależność obliczoną dla Polski na podstawie szacunków pracy nierejestrowanej według GUS. Zależność tę policzono dla lat 19982012 ze względu na terminy szacunków GUS (departament w Kielcach), podawanych z trzyletnim opóźnieniem. Posługując się metodą regresji liniowej, określono linię trendu, której wzór znajduje się w siatce wykresu. Pod nim zaprezentowano współczynnik $\mathrm{R}^{2}$, czyli wskaźnik determinacji ${ }^{21}$. Jego wartość wyniosła 0,468 , co oznacza brak zależności pomiędzy obiema zmiennymi.

Na rysunku 2 przedstawiono także zależność pomiędzy kwotą zasiłku pobieranego przez bezrobotnych w Polsce a zakresem pracy nierejestrowanej, ale liczoną na podstawie szacunków Schneidera. Zakres analizy obejmuje lata 1999-2014. W tym wypadku daje się zauważyć zadowalające dopasowanie obu zmiennych. Wartość wskaźnika determinacji wyniosła $81 \%(0,8122)$, co oznacza, że zmienna zależna, jaką jest zakres pracy na czarno, zmienia się według bardzo zbliżonego wzorca, podobnie jak poziom zasiłku dla

\footnotetext{
${ }^{21}$ Wskaźnik determinacji ma wartość 0-1. Jeśli jest mniejszy niż 0,5 oznacza to, że model jest niedopasowany do obserwacji, jeśli zaś wynosi 0,5-0,6 oznacza słabe dopasowanie, 0,6-0,8 - zadowalające, 0,8-0,9-dobre oraz $0,9-1$ - bardzo dobre.
} 
bezrobotnych. Może to wskazywać na silną zależność pomiędzy wysokością świadczenia a skalą pracy na czarno.

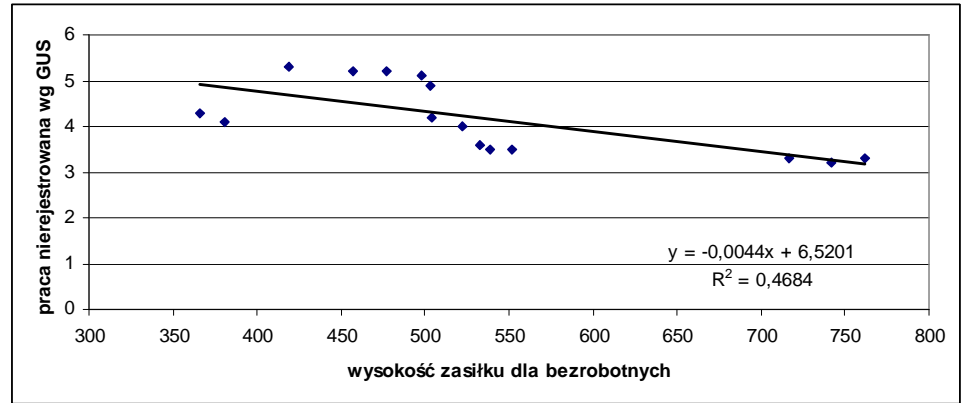

Rys. 1. Wykres rozrzutu między świadczeniem dla bezrobotnych w Polsce a pracą nierejestrowaną według szacunków Głównego Urzędu Statystycznego (GUS) w latach 1998-2012

Źródło: Obliczenia własne na podstawie tabeli 1 oraz tabeli 3.

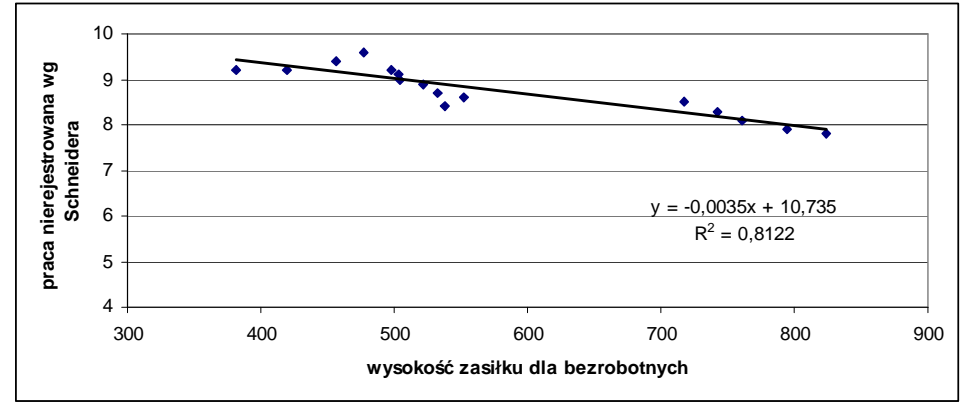

Rys. 2. Wykres rozrzutu między świadczeniem dla bezrobotnych w Polsce a pracą nierejestrowaną według szacunków Friedricha Schneidera w latach 1999-2014

Źródło: obliczenia własne na podstawie tabeli 1 oraz tabeli 3.

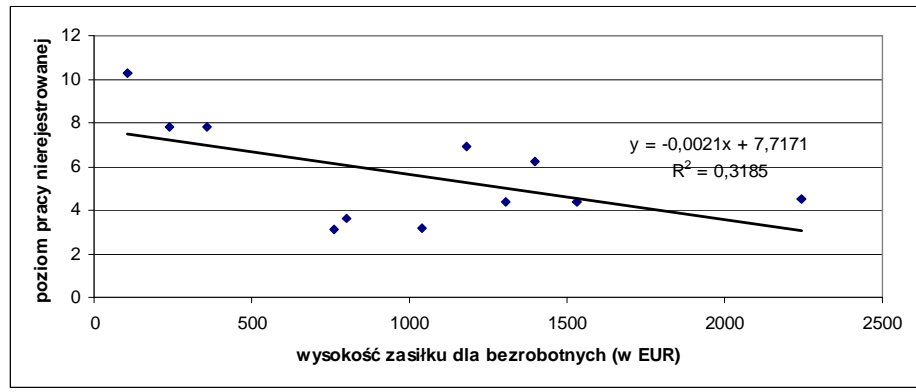

Rys. 3. Wykres rozrzutu pomiędzy świadczeniem dla bezrobotnych w 2014 r. w wybranych krajach Unii Europejskiej oraz pracą nierejestrowaną według Schneidera

Źródło: obliczenia własne na podstawie tabeli 2 oraz tabeli 4. 
Odmiennie przedstawia się sytuacja w wypadku badanej korelacji pomiędzy zasiłkiem a pracą nierejestrowaną w wybranych krajach europejskich. Wskaźnik determinacji osiągnął bardzo niskie wartości 0,3185 , co wskazuje na brak dopasowania ze strony obu zmiennych. Wydaje się, że istotny wpływ na ten wynik miał zróżnicowany sposób wyliczania i przyznawania kwoty przysługującego zasiłku.

\section{ZASILEK JAKO CZYNNIK SPRZYJAJACCY PRACY NIEREJESTROWANEJ W ŚWIETLE BADAŃ WŁASNYCH}

Zasiłek dla bezrobotnych jest narzędziem polityki rynku pracy o charakterze pasywnym i ma ono spełniać dwie funkcje. Pierwsza z nich to funkcja dochodowa mająca zapewnić określony poziom dochodów w okresie poszukiwania pracy, druga to funkcja motywacyjna. Wysoki poziom świadczenia umożliwia utrzymanie wysokiego standardu życia, jednak istnieje obawa, że funkcja dochodowa może stanąć w opozycji wobec motywacyjnej, prowadząc do zmniejszenia aktywności w poszukiwaniu pracy. Może także powodować nadmierną aktywizację tylko z chęci uzyskania dodatkowego świadczenia przy równoczesnym podejmowaniu pracy nierejestrowanej.

Badania rynku pracy przeprowadzone przez Państwową Agencję Rozwoju Przedsiębiorczości wskazują ${ }^{22}$, że osoby pobierające zasiłek bardzo często dorabiają przy pracach sezonowych w budownictwie, rolnictwie, gastronomii, hotelarstwie, a także w małych firmach produkcyjnych. Z opracowań przygotowywanych dla resortu pracy oraz raportów instytucji badawczych wynika, że do zasiłku dla bezrobotnych dorabia nawet 30-40\% osób zarejestrowanych w urzędach pracy. Częstą przyczyną podawaną przez beneficjentów świadczeń jest zbyt niski poziom zasiłku dla bezrobotnych. Równocześnie jego wygórowana wysokość skłania do działań mających na celu pobieranie pomocy i pracy poza ewidencją.

Tabela 5. Struktura odpowiedzi na pytanie: Co spowodowałoby, według Pana/i, podwyższenie zasiłku dla bezrobotnych?

\begin{tabular}{|c|c|c|c|c|c|c|c|c|}
\hline \multirow{2}{*}{$\begin{array}{c}\text { Skutki podwyższenia zasiłku dla } \\
\text { bezrobotnych }\end{array}$} & \multicolumn{7}{|c|}{ Struktura procentowa (\%) } \\
\cline { 2 - 10 } & 2007 & 2009 & 2010 & 2011 & 2012 & 2013 & 2014 & 2015 \\
\hline $\begin{array}{c}\text { Więcej pieniędzy i brak pracy na } \\
\text { czarno }\end{array}$ & 26,2 & 32,8 & 26,2 & 24,6 & 23,8 & 29,1 & 26,1 & 28,8 \\
\hline $\begin{array}{c}\text { Ograniczenie zakupów w szarej strefie } \\
\text { Poszerzenie patologii społecznej }\end{array}$ & 8,9 & 16,4 & 18,4 & 12,3 & 6,8 & 10,3 & 11,3 & 8,1 \\
\hline $\begin{array}{c}\text { Pobieranie zasiłku i dorabianie w } \\
\text { szarej strefie }\end{array}$ & 51,3 & 33,9 & 38,9 & 30,2 & 34,3 & 27,2 & 30,9 & 29,5 \\
\hline $\begin{array}{c}\text { Swiadome przechodzenie na zasiłek } \\
\text { bez dorabiania w szarej strefie }\end{array}$ & 15,0 & 17,1 & 13,2 & 8,8 & 9,6 & 9,7 & 9,1 & 8,5 \\
\hline Inny wariant & 1,5 & 0,4 & 0,3 & 0,6 & 1,2 & 0,7 & 1,5 & 1,1 \\
\hline RAZEM & $145 *$ & $1295^{*}$ & $136,1^{*}$ & 100,0 & 100,0 & 100,0 & 100,0 & 100,0 \\
\hline Brak odpowiedzi & 1,9 & 2,7 & 1,4 & 0,6 & 1,0 & 0,7 & 0,5 & 0,2 \\
\hline
\end{tabular}

* Suma wynosi ponad $100 \%$, gdyż ankietowani mogli wskazać wiele odpowiedzi.

Źródło: obliczenia własne na podstawie własnych badań ankietowych przeprowadzonych w gospodarstwach domowych w latach 2007-2015.

\footnotetext{
${ }^{22}$ Bilans Kapitału Ludzkiego, Polska Agencja Rozwoju Przedsiębiorczości, Uniwersytet Jagielloński, Warszawa 2013.
} 
Aby pogłębić identyfikację tej przyczyny zapytano respondentów w ramach własnych badań ankietowych prowadzonych w latach $2007-2015^{23}$ o skutek podwyższenia zasiłku dla bezrobotnych (tab. 5). Uzyskane odpowiedzi nie pozwalają na jednoznaczne rozstrzygnięcie dylematu. Blisko co trzecia osoba była zdania, że zwiększenie poziomu świadczenia spowoduje pobieranie zasiłku i dorabianie w szarej strefie $(51,3 \%$ w 2007 r., 33,9\% w 2009, 38,9\% w 2010, 34,3\% w 2012, 27,2\% w 2013 oraz ok. 30\% w 2011, 2014 i 2015 r.). Natomiast niewiele mniej - 23,8-29,1\% - ankietowanych było przekonanych, że zwiększenie zasiłku ograniczyłoby skalę pracy na czarno.

Tabela 6. Wysokość zasiłku dla bezrobotnych a nielegalne zatrudnienie

\begin{tabular}{|c|c|c|c|c|c|c|c|c|}
\hline \multirow{2}{*}{ Zasiłek a nielegalne zatrudnienie } & \multicolumn{7}{|c|}{ Struktura procentowa (\%) } \\
\cline { 2 - 9 } & 2007 & 2009 & 2010 & 2011 & 2012 & 2013 & 2014 & 2015 \\
\hline $\begin{array}{c}\text { Wysoki zasiłek sprzyja pracy na } \\
\text { czarno }\end{array}$ & 28,6 & 24,9 & 25,1 & 21,9 & 25,0 & 23,1 & 21,8 & 16,9 \\
\hline $\begin{array}{c}\text { Niski zasiłek sprzyja pracy na } \\
\text { czarno }\end{array}$ & 31,5 & 43,6 & 42,0 & 39,5 & 39,7 & 40,8 & 32,8 & 38,6 \\
\hline $\begin{array}{c}\text { Brak wpływu na nielegalne zatrud- } \\
\text { nienie }\end{array}$ & 33,5 & 28,8 & 30,6 & 37,8 & 34,4 & 34,8 & 44,8 & 44,0 \\
\hline RAZEM & 100,0 & 100,0 & 100,0 & 100,0 & 100,0 & 100,0 & 100,0 & 100,0 \\
\hline Brak odpowiedzi & 6,4 & 2,7 & 2,3 & 0,8 & 0,9 & 1,3 & 0,6 & 0,5 \\
\hline
\end{tabular}

Źródło: obliczenia własne na podstawie własnych badań ankietowych przeprowadzonych w gospodarstwach domowych w latach 2007-2015.

Podobnie niejednoznaczne są odpowiedzi na bezpośrednio postawione pytanie o to, jaka wysokość sprzyja szarej strefie rynku pracy (tab. 6). Najczęściej wybieranym wariantem odpowiedzi do 2014 r. było stwierdzenie, że „niski zasiłek sprzyja pracy na czarno”. Wskazało na niego 31,5-43,6\% osób biorących udział w badaniu. Od 28,8\% w 2009 r. do 44,8\% respondentów w 2014 uznało, że wysokość pomocy społecznej nie wpływa na aktywność w szarej strefie rynku pracy.

\section{PODSUMOWANIE}

Według komisarza Unii Europejskiej do spraw zatrudnienia, spraw społecznych i wyłączenia społecznego Laszlo Andora praca na czarno jest problemem, który powinien być rozpatrywany na wielu płaszczyznach. Taka forma zatrudnienia naraża pracowników na niebezpieczne warunki pracy i brak zabezpieczenia socjalnego. Równocześnie jednak obniża wpływy do budżetu państwa i podważa zbudowane przez poszczególne kraje systemy zabezpieczenia społecznego. Wynika $\mathrm{z}$ tego, że podjęcie skutecznych działań w zakresie ograniczenia pracy nierejestrowanej leży w interesie nie tylko poszczególnych krajów Unii Europejskiej, ale także samych pracowników.

\footnotetext{
${ }^{23}$ Badania własne przeprowadzono na celowej próbie 686 gospodarstw domowych w maju 2007 r., 750 gospodarstw domowych w maju 2009 r., 1084 gospodarstw domowych w kwietniu i maju 2010 r., 1201 gospodarstw domowych w maju 2011 r., 1230 gospodarstw domowych w styczniu 2012 r., 1128 gospodarstw domowych w styczniu 2013 r., 857 gospodarstw domowych w styczniu 2014 r. oraz 852 gospodarstw domowych w styczniu 2015 r. W badaniach ankietowych przeprowadzonych w maju 2007 r. wzięły udział gospodarstwa domowe oraz podmioty gospodarcze z terenu całej Polski, natomiast wywiady w latach 2009-2015 zostały przeprowadzone na terenie województwa podkarpackiego. Ankiety były skierowane do osób powyżej 20. roku życia o zróżnicowanym poziomie dochodów oraz standardzie życia.
} 
Przyjmuje się, że jednym z determinantów szarej strefy rynku pracy są nieodpowiednie regulacje publiczne, w tym także zasiłki dla bezrobotnych, których konstrukcja może skłaniać do podejmowania nierejestrowanego zatrudnienia. Badania empiryczne rynku pracy często dowodzą, że wypłacanie niskich świadczeń osobom bezrobotnym zmusza je do pracy na czarno, gdyż kwota pomocy społecznej nie wystarcza nawet na potrzeby egzystencjonalne. Równocześnie w literaturze przedmiotu podkreśla się, że zasiłek dla bezrobotnych jest wprawdzie nieodzownym narzędziem polityki społecznej państwa, niemniej jednak przyznawanie wysokich świadczeń sprawia, że zatrudnienie w oficjalnej gospodarce może się stać mało atrakcyjne, zwłaszcza dla osób o niskich kwalifikacja, których wynagrodzenie jest zbliżone do płacy minimalnej.

W efekcie może to wpływać demoralizująco i zachęcać pracowników do przepracowywania wymagalnego ustawowo okresu, po którym nabywa się prawo do zasiłku i jednoczesnej aktywności w szarej strefie rynku pracy. Pokusą są tu nie tylko świadczenia pieniężne zbliżone do wysokości płacy minimalnej, którą najczęściej otrzymują osoby o niskich kwalifikacjach, ale także wysokie składki na ubezpieczenie społeczne (w tym zdrowotne). Należy podkreślić, że częstą formą zatrudnienia w sytuacji deficytu miejsc pracy w Polsce jest samozatrudnienie, a zarejestrowanie się jako osoba bezrobotna gwarantuje nie tylko niemałe dochody, ale także ubezpieczenie zdrowotne.

W przeprowadzonej analizie statystycznej wykazano, że wysokość świadczenia otrzymywanego przez osoby bezrobotne w Polsce w latach 1999-2014 wpływa na zakres pracy nierejestrowanej obliczanej metodą MIMIC (Multiple Indicators Multiple Causes). Wysokość zasiłku w ponad 80\% determinuje zakres podejmowanej pracy w szarej strefie. Natomiast ze względu na zróżnicowany sposób wyliczania kwoty przysługującego zasiłku nie wykazano zależności statystycznej pomiędzy wysokością badanego świadczenia a zakresem pracy nierejestrowanej w wybranych krajach europejskich.

Badania ankietowe przeprowadzane na próbie celowej około 1000 gospodarstw domowych także nie rozstrzygnęły jednoznacznie kwestii wysokości zasiłku motywującego bądź zmuszającego do podejmowania nielegalnej pracy. Sama wysokość świadczenia nie jest jedyną determinantą. Należy także wziąć pod uwagę moralność podatkową obywateli (w wypadku Polski jest ona dość niska), skłonność do kombinatorstwa (często odziedziczoną po okresie gospodarki centralnie planowanej) czy też problem znalezienia pracy w sferze oficjalnej.

Wydaje się, że wysokość zasiłku w Polsce może skłaniać osoby o najniższych dochodach do przepracowywania ustawowego, wymaganego czasu pracy, po czym pobierania zasiłku i pracy na czarno przy jednoczesnej rezygnacji z legalnego zatrudnienia. Należy jednak pamiętać, że w obecnej sytuacji deficytu na rynku pracy bardzo trudno zachować ciągłość stażu zatrudnienia, zatem postawa polegająca na celowym przepracowywaniu ustawowego okresu pracy uprawniającego do poboru świadczenia wydaje się rzadsza. Może ona dotyczyć pracowników sezonowych lub osób rzeczywiście tracących pracę, nisko wykwalifikowanych lub prowadzących nielegalną lub nieewidencjonowaną działalność gospodarczą. W tym wypadku przepracowanie wymaganego okresu oraz uzyskanie prawa do zasiłku i równocześnie do ubezpieczenia zdrowotnego mogą znacząco ograniczyć koszty wysokiej składki na ubezpieczenie społeczne płaconej przez osoby prowadzące jednoosobową działalność gospodarczą. 


\section{LITERATURA}

[1] Arbeitslosengeld 1 Rechner, www.brutto-netto-rechner.info.

[2] Bednarski M., Kokoszczyński R., Nieoficjalna gospodarka i jej społeczne następstwa, „Ekonomista" 1988/3-4, s. 702-703.

[3] Bilans Kapitału Ludzkiego, Polska Agencja Rozwoju Przedsiębiorczości, Uniwersytet Jagielloński, Warszawa 2013.

[4] Fridman E., Johnson S., Kaufmann D., Zoido-Labton P., Dodging the grabbing hand: The determinants of unofficial activity in 69 countries, ,Journal of Public Economics” 76/4 (2000).

[5] Gaudemet P., Finanse publiczne, Polskie Wydawnictwo Ekonomiczne, Warszawa 2000, s. 575 i n.

[6] Gutmann P.M., The Subterranean Economy, „Financial Analysts Journal” 1977/33.

[7] Jobseeker's Allowance (JSA), 2015, www.gov.uk.

[8] Johnson S., Kaufmann D., Zoido-Labton P., Corruption, public finances and the unofficial economy, The World Bank, Washington 1998.

[9] Komisja Europejska, Komunikat Prasowy, Bruksela, 9 kwietnia 2014 r., w sprawie skuteczniejszego zapobiegania pracy nierejestrowanej i zniechęcania do niej, http:// Europa.eu/rapie/Press-release_IP-14-387.

[10] Mateman S., Renooy P.H., Undeclared Labour in Europe: Towards an Integrated Approach of Combating Undeclared Labour, Regoiplan, Amsterdam 2001.

[11] Mróz B., Gospodarka nieoficjalna w systemie ekonomicznym, Szkoła Główna Handlowa, Warszawa 2002, s. 42.

[12] Rachunki narodowe wg sektorów i podsektorów instytucjonalnych w latach 2007-2011, Studia i analizy statystyczne, GUS, Warszawa 2013.

[13] Rachunki narodowe wg sektorów i podsektorów instytucjonalnych w latach 2009-2012, Studia i analizy statystyczne, GUS, Warszawa 2014.

[14] Schneider F., Size and Development of the Shadow Economy of 31 European and 5 other OECD Countries from 2003 to 2013, www. uni-linz.ac.at, 2013.

[15] Schneider F., The shadow economies of Western Europe, ,Journal of the Institute of Economic Affairs", 17/3 (1997).

[16] Shneider F., The Size of the Shadow Economies of 145 Countries all over the World, First Results over the Period 1999 to 2003, „IZA, Discussion Paper” 2004/1431.

[17] Schneider F., Raczkowski K., Mróz B., Shadow economy and tax evasion in the EU, „Journal of Money Laundering Control” 18/1 (2015), s. 12.

[18] Tanzi V., Uses and abuses of estimates of the underground economy, „The Economic Journal” 109/456 (1999).

[19] The Unemployment Benefits Act (WW), www. Iamexpat.nl.

[20] Thomas J.J., Informal Economic Activity, LSE, Handbooks in Economics, Harvester Wheatsheaf, London 1992.

[21] Unemployment benefits 2015, National Social Security Institute, www.nssi.bg.

[22] Unemployment benefits, Public Employment Service Austria (AMS), www.ams.at.

[23] Unemployment Benefits, www.nav.no.

[24] Wie hoch ist der Hartz IV - Regelsatz ab dem 01.01.2015?, Sozialrecht, 2014, www.refrago.de.

[25] Your social security rights in Grece, Employment, Social and Inclusion, European Commission, 2013, http://ec.europa.eu; OAED Unemployment Benefits in Greek, www.oaed.gr.

[26] Your social security rights in Romania, Employment, Social and Inclusion, European Commission, 2013, http://ec.europa.eu; U.S. Social Security Administration, www.ssa.gov.

[27] Zarychta H., Szara strefa rynku pracy w Polsce, cz. I., „Praca i Zabezpieczenia Społeczne” 1993/12, s. 11. 


\section{UNEMPLOYMENT BENEFITS AS DETERMINANTS OF UNDECLARED WORK}

Workers compensation is aimed to, on the one hand, to ensure the maintenance of the existing standard of living of the beneficiary, and on the other one, it should motivate him to actively seek new employment. In the literature regarding the subject we can come across a thesis that too low workers compensation for the unemployed may force them to seek employment in the gray economy. However,, it indicates that too high levels of unemployment benefit or close to the minimum wage may encourage to extend the unemployment period to the maximum and during that time the unemployed may seek unregistered labor.

The paper presents the level of unemployment benefits and the extent of undeclared work in Poland and selected countries in the period 1999-2014. On the basis of statistical data based on linear regression, I have investigated the relationship between the maximum height of benefits granted to the unemployed and the extent of undeclared work in Poland and in selected countries. Fragments of self-conducted study were presented in this article for the years 2007-2014 survey regarded gray economy and unregistered labor. The article attempts to assess the impact of the benefit for the unemployed on their willingness to take undeclared work.

Keywords: labor market, undeclared work, unemployment, unemployment benefit

DOI: $10.7862 /$ rz.2015.mmr.44

Tekst złożono w redakcji: lipiec 2015

Przyjęto do druku: wrzesień 2015 